\title{
PENINGKATAN PROFESIONALISME GURU PENDIDIKAN AGAMA ISLAM (PAI) MELALUI PROGRAM SERTIFIKASI
}

\author{
Dewi Masitoh \\ dewimasitohdeem18@gmail.com \\ UIN Raden Intan Lampung
}

\begin{abstract}
This article aims to analyze the driving and inhibiting factors for increasing the professionalism of Islamic Education teachers after being given a certification allowance. The type of this research is Field Research, the data collection method uses interviews, documentation and observation, to check the validity of the data using triangulation techniques and the data is analyzed in three stages, namely data reduction, data presentation, and conclusions. The results showed that the increase in professionalism of Islamic Education teachers through the certification program was satisfactory, but it had not gone as expected. The certification program which aims to improve teacher professionalism and welfare has not been implemented properly. This is evident from the research findings which reveal that certified PAI teachers have not met the professional teacher criteria as expected. It is hoped that the positive contribution of this article can become a reference for similar studies in the future, and can be a reference in order to achieve teacher professionalism through the certification program.
\end{abstract}

\section{Keywords: Certification Program, Profesionalism, Religion Teachers}

\begin{abstract}
Abstrak
Artikel ini bertujuan untuk menganalisis faktor pendorong dan penghambat peningkatan profesionalisme guru PAI setelah diberikan tunjangan sertifikasi. Jenis penelitian ini adalah penelitian lapangan (Field Research), metode pengumpulan data menggunakan wawancara (interview), dokumentasi dan observasi, untuk pengecekan keabsahan data menggunakan teknik triangulasi serta data dianalisa dengan tiga tahap yaitu reduksi data, penyajian data, dan kesimpulan. Hasil penelitian menunjukkan bahwa peningkatan profesionalisme guru PAI melalui program sertifikasi sudah cukup memuaskan, namun belum berjalan sebagaimana yang diharapkan. Program sertifikasi yang
\end{abstract}


tujuannya untuk meningkatkan profesionalisme dan kesejahteraan guru belum terlaksana sebagaimana mestinya. Hal ini terbukti dari temuan penelitian yang mengungkap bahwa guru-guru PAI bersertifikasi belum memenuhi kriteria-kriteria guru profesional sebagaimana yang diharapkan. Kontribusi positif dari artikel ini diharapkan dapat menjadi acuan bagi penelitian-penelitian sejenis dikemudian hari, serta dapat menjadi acuan guna tercapainya profesionalisme guru melalui program sertifikasi.

\section{Kata Kunci: Sertifikasi, Profesionalisme, Guru}

\section{A. Pendahuluan}

Guru profesional adalah seseorang yang terlatih dan terdidik dengan baik, serta memiliki banyak pengalaman dibidangnya. ${ }^{1}$ Menghadapi berbagai tantangan pendidikan di era revolusi indrusti 4.0, sangat dibutuhkan sosok guru yang dapat bekerja secara profesional, modern, bermutu, tentunya dengan dukungan kesejahteraan yang memadai. Hal itu disebabkan karena guru adalah sosok pendidik yang menjadi contoh, tokoh dan panutan bagi para peserta didik dan lingkungannya, maka seorang guru wajib memiliki standar kualitas pribadi tertentu, yang didalamnya mencakup wibawa, tanggungjawab, disiplin, dan profesionalisme.

Problematika tentang kualitas pendidikan di Indonesia sudah lama menjadi perhatian dan sorotan dari berbagai perspektif, diantaranya sorotan terhadap rendahnya kualitas pendidikan yang dihubungkan dengan profesionalisme guru. Pendapat ini sangat beralasan, karena studi-studi menunjukkan bahwa guru merupakan factor penting yang mempengaruhi proses belajar peserta didik.

Posisi strategis guru untuk meningkatkan mutu hasil pendidikan sangat dipengaruhi oleh kemampuan profesional mengajar dan tingkat kesejahteraannya. $^{2}$ Kualitas para guru dapat diketahui berdasarkan tingkat

1. Kunandar, Guru Profesional Implementasi Kurikulum Tingkat Satuan Pendidikan (KTSP) dan Persiapan Menghadapi Sertifikasi Guru, (Jakarta: Raja Grafindo Persada, 2007), h. 46

2. Syaeful Bahri Djamarah, Guru dan Anak Didik dalam Interaksi Edukatif, (Jakarta: 
profesionalisme mereka dalam tugas mengajar peserta didik, namun yang tejadi justru sebaliknya. Masih dijumpai guru-guru yang megalami kesulitan dalam membeikan inovasi dalam pembelajaran.

Kelemahan tersebut juga terdapat pada guru Pendidikan Agama Islam (PAI), bahkan guru PAI juga masih memiliki kelemahan-kelemahan lainnya. Kelemahan tesebut diantaranya: (1) rendahnya apresiasi terhadap guru PAI, hal ini dapat diketahui dari minimnya apresiasi pemerintah tehadap kinerja guru PAI.; (2) kurangnya sikap profesional guru PAI yang dicirikan dengan kurangnya kemampuan dalam menyampaikan bahan ajar kepada peserta didik, metode dan strategi pembelajaran yang digunakan, serta minimnya persiapan dalam mengajar.

Secara umum, gambaran kompetensi guru PAI itu sebenarnya paling paling kompleks. Dapat diasumsikan bahwa tugas seorang guru PAI sama dengan tugas tujuh orang guru umum. Dikatakan demikian karena materi ajar PAI meliputi banyak disiplin Ilmu, diantaranya: Ilmu tauhid (Akidah), Ilmu Al-Qur'an, Ilmu Akhlak, Ilmu Fiqih, Ilmu Hadits, Sejarah Kebudayaan Islam, dan Bahasa Arab. Pelajaran Bahasa Arab memang tidak termasuk dalam komponen-komponen PAI, akan tetapi Bahasa Arab merupakan ilmu alat yang senantiasa melekat pada materi ajar PAI. Guru PAI tidak mungkin dapat menguasai materi PAI tanpa menguasai Bahasa Arab. Masalah ini baru menyangkut tentang tuntutan penguasaan materi PAI, padahal untuk menjadi guru PAI yang professional juga harus memenuhi tuntutan-tuntutan lainnya, sehingga dibutuhkan upaya-upaya peningkatan profesionalisme guru PAI secara kontinyu.

Langkah awal yang telah dilakukan adalah melakukan sertifikasi guru kepada guru-guru dalam jabatan sebagai suatu bentuk pengakuan terhadap status profesional mereka. Langkah itu telah dimulai sejak tahun 2005, berdasarkan pada amanat Undang-Undang Guru dan Dosen (UUGD) dan peraturan Pemerintah tentang Standar Nasional Pendidikan bahwa guru

Rineka Cipta,2000), h. 32 
adalah sebuah pekerjaan profesional, maka diperlukan usaha untuk menjadikan guru sebagai suatu pekerjaan profesional.

Undang-undang Nomor 14 Tahun 2005 tentang Guru dan Dosen disahkan pada Desember 2005. Mulai saat itu, istilah sertifikasi mejadi sangat populer di kalangan pendidikan dan menjadi pembicaraan yang hangat di masyarakat. Diberlakukannya undang-undang tersebut minimal memiliki tiga fungsi. Pertama, sebagai landasan yuridis bagi guru dari perbuatan semena-mena dari peserta didik, orang tua, dan masyarakat. Kedua, sebagai usaha dalam meningkatkan profesionalisme guru. Ketiga, untuk meningkatkan kesejahteraan guru.

Berdasarkan hal tersebut di atas, sertifikasi guru merupakan program yang menjanjikan bagi guru terutama guru PAI. Selain tujuan pemerintah ingin meningkatkan profesionalisme guru, juga ingin meningkatkan taraf hidup guru. Hal inipun mendapat sambutan hangat di kalangan pendidikan, terutama para guru Pendidikan Agama Islam.

Kebijakan sertifikasi guru dalam rangka peningkatan terhadap status profesional guru sudah berjalan kurang lebih 13 tahun. Diamsusikan bahwa dengan adanya sertifikasi akan berdampak positif bagi guru seperti meningkatnya wawasan dan pengetahuan tentang tugas dan fungsi guru sebagai tenaga profesional, meningkatnya penguasaan terhadap kurikulum dan pembelajaran serta mengubah mindset guru sebagai sebuah pekerjaan profesional. Singkatnya dengan adanya program sertifikasi diharapkan terjadi peningkatan profesionalisme guru melalui usahan peningkatan mutu proses dan hasil pembelajaran, serta peningkatan kinerja dan mutu pendidikan secara nasional.

\section{B. Pembahasan}

\section{1) Teori}

\section{a. Pengertian Sertifikasi Guru}

Landasan utama yang menjadi acuan program sertifikasi dan kompetensi guru adalah Undang-Undang RI Nomor 20 Tahun 
2003 tentang Sistem Pendidikan Nasional, pada pasal 42 ayat 1 yang mengatakan bahwa "Pendidik harus memiliki kualifikasi minimum dan sertifikat sesuai dengan jenjang kewenangan mengajar, sehat jasmani dan rohani, serta memiliki kemampuan untuk mewujudkan tujuan pendidikan nasional”.

Sertifikasi berasal dari kata certification yang memiliki arti diploma atau pengakuan secara resmi kompetensi seseorang untuk memangku jabatan profesional. Istilah sertifikasi dapat diartikan sebagai surat keterangan (sertifikat) dari lembaga berwenang yang diberikan kepada profesi, dan sekaligus sebagai pernyataan (lisensi) terhadap kelayakan profesi untuk melaksanakan tugas. Sertifikasi tersebut dapat diikuti oleh guru dalam jabatan yang telah memiliki kualifikasi akademik sarjana (S1) atau diploma empat (D-IV). ${ }^{3}$

Berdasarkan pengertian di atas, dapat diketahui bahwa program sertifikasi merupakan pemberian pengakuan secara resmi kompetensi seorang guru untuk memangku jabatan profesional sesuai dengan kualifikasi akademik yang dimilikinya, serta sehat secara jasmani maupun rohani.

Bagi seorang pendidik, sertifikasi menurut National Commision Educational Services (NCES), "Certification is a procedure whereby the states evaluates and reviews a teacher candidates's credentials and provides him or her a license to teach”. Sertifikasi guru merupakan suatu proses untuk memberikan sertifikat kepada guru yang dapat memenuhi standar kualifikasi dan standar kompetensi. Sertifikat pendidik adalah surat keterangan yang diberikan suatu lembaga pengadaan tenaga kependidikan yang terakreditasi sebagai bukti formal kelayakan profesi guru, yaitu dengan memenuhi kualifikasi pendidikan minimum dan menguasai kompetensi minimum sebagai agen pembelajaran. Pemberian sertifikat pada dasarnya mengacu pada sebuah proses pemberian pengakuan terhadap suatu profesi tertentu sebagai bukti kelayakan yang bersangkutan untuk melakukan praktik profesinya.

3. Imam Wahyudi, Mengejar Profesionalisme Guru: Strategi Praktis Mewujudkan Citra Guru Profesional, (Jakarta: Prestasi Pustaka, 2012), h. 131 
Sertifikat pendidik adalah program pemerintah untuk meningkatkan kompetensi dan standar profesionalisme serta kebijakan pemerintah untuk menaikkan martabat pendidik dengan memberikan penghargaan agar guru dapat meningkatkan kualitas pendidik. Selain itu, para guru yang telah disertifikasi harus menyadari bahwa era sekarang adalah era teknologi dan informasi, sehingga mereka perlu belajar terus-menerus agar dapat menyesuaikan diri dengan perkembangan zaman, terutama perkembangan dalam bidang teknologi dan informasi. ${ }^{4}$

Kebijakan program ini, perlu dihargai oleh banyak pihak terutama orang-orang yang terlibat dalam dunia Pendidikan, hal ini karena kebijakan tersebut befungsi untuk mengangkat harkat dan martabat guru. Sasarannya supaya mereka lebih dihargai oleh pengguna jasa profesi ini dan tentunya juga akan diikuti dengan standar upah dan penghargaan yang layak bagi guru yang memiliki sertifikat pendidik tersebut. ${ }^{5}$

Menanggapi hal tersebut, dalam jurnal International pendidikan dijelaskan bahwa:

Expectation of the enactment of the teacher certification program is to obtain educators who have qualified, to increase the qualifications of educators and education, to level up educational management processes of teaching and learning, and to improve the quality of human resources of the nation. Teachers who have been certified educator is expected to increase various competencies that can deliver the performance of teachers in a real professional function. If every teacher are embedded soul and spirit to understand the certification as a means to an end, the teacher will make various efforts to improve performance, dedication, quality of work that is able to prove that the educator function is a professional function. ${ }^{6}$

Berdasarkan hal tersebut, diasumsikan bahwa harapan diberlakukannya program sertifikasi guru adalah untuk menghasilkan pendidik yang memiliki kualifikasi, serta untuk meningkatkan proses

4 Yopa Taufik Saleh, "Sertifikasi Untuk Meningkatkan Profesionalisme Guru," NATURALISTIC: Jurnal Kajian Penelitian Pendidikan Dan Pembelajaran, 2017, https://doi.org/10.35568/naturalistic.v1i1.42.

5 Hujair A.H. Sanaky, "Sertifikasi Dan Profesionalisme Guru Di Era Reformasi Pendidikan,” Jurnal Pendidikan Islam, Jurusan Tarbiyah, 2005.

6 Zuli Nuraeni and Heri Retnawati, "The Post-Certification Performance of Mathematics Teachers,” The Online Journal of New Horizons in Education, 2016. 
manajemen pendidikan, pembelajaran dan meningkatkan sumber daya manusia.

Sertifikasi ini merupakan salah satu cara dalam meningkatkan profesionalisme guru, sebagai sebuah proses ilmiah yang memerlukan pertanggung-jawaban akademis dan moral. Dalam sertifikasi tercermin adanya suatu uji kelayakan yang harus dijalani seorang guru terhadap kriteria-kriteria yang secara ideal telah ditetapkan. Pelaksanaan sertifikasi dilaksanakan dengan mendata semua yang dimiliki oleh setiap guru, dapat berupa ijazah sarjana atau diploma, tanda lulus kursus, dan tanda telah mengikuti pelatihan. Data tersebut juga dapat berupa hasil karya ilmiah atau kepesertaan dalam sebuah kegiatan pengabdian masyarakat.

\section{b. Badan Hukum Pelaksanaan Program Sertifikasi}

Dasar pemikiran dan landasan pelaksanaan kegiatan sertifikasi bagi guru adalah sebagai berikut:

1. Undang-Undang Nomor 20 Tahun 2003 tentang Sistem Pendidikan Nasional

2. Undang-Undang Nomor 14 Tahun 2005 tentang Guru dan Dosen

3. Peraturan Pemerintah Nomor 19 Tahun 2005 tentang Standar Nasional Pendidikan

4. Peraturan Menteri Pendidikan Nasional Nomor 16 Tahun 2005 tentang Standar Kualifikasi dan Kompetensi Pendidik

5. Fatwa pendapat Hukum Menteri Hukum dan Hak Asasi Manusia No.I.UM.01.02-253

6. Peraturan Menteri Pendidikan Nasioanl Nomor 18 Tahun 2007 tentang Sertifikasi bagi Guru dalam Jabatan

7. Peraturan Mendiknas Nomor 40 Tahun 2007 tentang Sertifikasi Guru dalam Jabatan melalui Jalur Pendidikan

8. Keputusan Mendiknas Nomor 056/O/2007 tentang pembentukan Konsorsium Sertifikasi Guru (KSG)

9. Keputusan Mendiknas No.057/O2007 tentang Penetapan Perguruan Tinggi Penyelenggara Sertifikasi Guru dalam Jabatan. ${ }^{7}$

Berdasarkan dasar di atas, landasan pelaksanaan program sertifikasi guru berdasar pada 9 landasan pokok yang terdiri dari

\footnotetext{
7.Jamal Ma’ruf Asmani, 7 Tips Cerdas \& Efektif Lulus Sertifikasi Guru, (Yogyakarta:
} 
undang-undang tentang sistem pendidikan nasional, undang-undang guru dan dosen, peraturan menteri pendidikan nasional, serta keputusan menteri pendidikan nasional.

Menurut sumber lain, menyebutkan bahwa dasar hukum yang digunakan sebagai acuan pelaksanaan sertifikasi guru dalam jabatan tahun 2016 adalah sebagai berikut:

1. Undang-Undang Nomor 20 Tahun 2003 tentang Sistem Pendidikan Nasional

2. Undang-Undang Republik Indonesia Nomor 14 Tahun 2005 tentang Guru dan Dosen

3. Undang-Undang Republik Indonesia Nomor 23 Tahun 2014 tentang Pemerintahan Daerah

4. Undang-Undang Republik Indonesia Nomor 28 Tahun 2004 tentang Perubahan atas Nomor 16 Tahun 2001 tentang Yayasan

5. Peraturan Pemerintah Republik Indonesia Nomor 74 Tahun 2008 tentang Guru

6. Peraturan Pemerintah Republik Indonesia Nomor 32 Tahun 2013 tentang perubahan atas Peraturan Pemerintah Nomor 19 Tahun 2005 tentang Standar Nasional Pendidikan

7. Peraturan Menteri Pendidikan Nasional Nomor 16 Tahun 2007 tentang Standar Kualifikasi dan Kompetensi Guru

8. Peraturan Menteri Pendidikan Nasional Nomor 27 Tahun 2008 tentang Konselor/Pendidikan Profesi Konselor

9. Peraturan Menteri Pendidikan dan Kebudayaan Nomor 5 Tahun 2012 tentang Sertifikasi Guru dalam Jabatan

10. Peraturan Menteri Pendidikan dan Kebudayaan Nomor 62 Tahun 2003 tentang Sertifikasi Guru dalam Jabatan dalam rangka Penataan dan Pemerataan Guru

11. Peraturan Menteri Pendidikan dan Kebudayaan Nomor 68 Tahun 2014 tentang Peran Guru TIK dan KKPI dalam Implementasi Kurikulum 2013

12. Peraturan Menteri Pendidikan dan Kebudayaan Nomor 111 Tahun 2014 tentang Bimbingan dan Konseling pada Pendidikan Dasar dan Pendidikan Menengah. ${ }^{8}$

Secara garis besar, program sertifikasi guru ini mempunyai beberapa landasan hukum yang kuat sebagai dasar utama pelaksanaan program sertifikasi di lapangan yang diantaranya berupa undang-undang tentang sistem pendidikan nasional, undang-undang guru dan dosen, peraturan

Diva Press, 2009), h. 28-29

8. Tim Penyusun, Sertifikasi Guru dalam Jabatan: Buku Pedoman 1 Penetapan Peserta, 
menteri pendidikan nasional, dan lain sebagainya.

\section{c. Pengertian Profesionalisme Guru PAI}

Profesionalisme berasal dari kata profesi yang artinya suatu bidang pekerjaan yang ingin atau akan ditekuni oleh seseorang. Profesi juga dapat diartikan sebagai suatu jabatan atau pekerjaan tertentu yang mensyaratkan pengetahuan dan keterampilan khusus yang diperoleh dari pendidikan akademis yang intensif. ${ }^{9}$

Secara bahasa, istilah profesi berasal dari bahasa Inggris, yaitu profession atau bahasa latin, profecus, yang artinya mengakui, adanya pengakuan, menyatakan mampu, atau ahli dalam melakukan suatu pekerjaan yang mempersyaratkan pendidikan tinggi bagi pelakunya yang ditekankan pada pekerjaan mental, yakni adanya persyaratan pengetahuan teoritis sebagai instrumen untuk melakukan perbuatan praktis, bukan pekerjaan manual. Jadi suatu profesi harus memiliki tiga pilar pokok, yaitu pengetahuan, keahlian, dan persiapan akademik. $^{10}$

Profesional adalah "suatu pekerjaan atau kegiatan yang dilakukan oleh seseorang dan menjadi sumber penghasilan kehidupan yang memerlukan keahlian atau kecakapan yang memenuhi mutu atau norma tertentu serta memerlukan pendidikan profesi. (UU Nomor 14 Tahun 2005 tentang Guru dan Dosen)”. ${ }^{11}$ Menurut sumber lain, definisi profesional ialah,

The definition of professionalism in general terms what we have come to understand by the concept of a 'profession', a set of criteria which are both inclusive and also exclusive of a large body of people who might describe themselves as 'professional' but who do not meet those stringent standards. For school systems in many parts of the world, struggling to recruit teachers, these are aspirational criteria that may not all be met on initial appointment but nonetheless provide a benchmark for on-going professional development. In well-resourced countries with demanding and competitive levels of

(Jakarta: Kementerian Pendidikan \& Kebudayaan, 2016), h. 2-3

9. Rusman, Model-Model Pembelajaran: Mengembangkan Profesionalisme Guru, (Jakarta: Rajawali Pers, 2013), h. 15-16

10 Sutarmanto, “Kompetensi Dan Profesionalisme Guru,” Jurnal Visi Ilmu Pendiidkan, 2015.

11 ABBAS Abbas, "PENGEMBANGAN PROFESIONALISME GURU,” Adaara: Jurnal Manajemen Pendidikan Islam, 2018, https://doi.org/10.35673/ajmpi.v7i1.310. 
qualification, the nature of professionalism will often exceed those baseline criteria. Traditional criteria that gave a license to teach four or five decades ago, extending from recruitment to retirement, require to be revisited and refined in a fast moving social and economic world in which what it means to be a teacher is changing, and is likely to continue to change over the next few decades. ${ }^{12}$

Berdasarkan definisi di atas, maka dapat dijelaskan bahwa profesi merupakan suatu pekerjaan atau keahlian yang mensyaratkan kompetensi intelektualitas, sikap dan keterampilan tertentu yang diperoleh melalui sebuah proses pendidikan secara akademis serta memerlukan teknik dan prosedur ilmiah, serta memiliki dedikasi. Hal tersebut dilakukan agar guru dapat melaksanakan pekerjaan tersebut secara efektif dan efisien serta berhasil guna.

Profesionalisme guru merupakan suatu kondisi, nilai, arah, tujuan dan kualitas suatu keahlian dan kewenangan dalam bidang pendidikan dan pengajaran yang berkaitan dengan pekerjaan seseorang yang menjadi mata pencaharian. Sementara itu, guru yang profesional adalah guru yang memiliki kompetensi yang dipersyaratkan untuk melakukan tugas pendidikan dan pengajaran. Dengan kata lain, maka dapat dipahami bahwa pengertian guru profesional adalah orang yang memiliki kemampuan dan keahlian khusus dalam bidang keguruan sehingga ia mampu melakukan tugas dan fungsinya sebagai guru dengan kemampuan maksimal. Guru yang profesional adalah orang yang terdidik dan terlatih dengan baik, serta memiliki pengalaman yang kaya di bidangnya. ${ }^{13}$

Profesionalisme menunjuk kepada komitmen para anggota suatu profesi untuk meningkatkan kemampuan profesionalnya dan terus-menerus mengembangkan strategi-strategi yang digunakannya dalam melakukan pekerjaan yang sesuai dengan profesinya.. ${ }^{14}$ Institute, 2012.

12 John Macbeath, "Future of Teaching Profession,” Education International Research

13. Kunandar, Guru Profesional Implementasi Kurikulum Tingkat Satuan Pendidikan (KTSP) dan Persiapan Menghadapi Sertifikasi Guru, h. 46-47

14. Buchari Alma, Guru Profesional: Menguasai Metode dan Terampil Mengajar, h. 130 
Berdasarkan penjelasan di atas dapat dijelaskan bahwa, profesi adalah suatu jabatan, profesional adalah kemampuan atau keahlian dalam memegang suatu jabatan tertantu, sedangkan profesionalisme adalah keahlian dalam suatu profesi. Dapat diketahui, profesionalisme guru dalam penelitian ini adalah profesionalisme guru dalam bidang studi tertentu, yakni seorang guru yang memiliki kemampuan dan keahlian khusus dalam bidang studi tertentu serta telah berpengalaman dalam mengajar sehingga ia mampu melakukan tugasnya sebagai guru dengan kemampuan yang maksimal serta memiliki kompetensi sesuai dengan kriteria guru profesional, dan profesinya itu telah menjadi sumber mata pencaharian.

Berdasarkan penjelasan di atas, menurut sebuah pendapat ada delapan kriteria yang harus dipenuhi agar suatu pekerjaan dapat disebut sebagai profesi, yaitu; (1) panggilan pekerjaan yang sepenuh waktu; (2) kecakapan/keahlian; (3) kebakuan yang universal; (4) pengabdian; (5) kecakapan diagnostik dan kompetensi aplikatif; (6) otonomi; (7) kode etik, dan (8) klien. ${ }^{15}$

Kriteria ini berlaku pada semua profesi, termasuk profesi guru PAI. Di samping itu, guru PAI masih diikat oleh kreteria tertentu sesuai dengan tugasnya sebagai pendidik agama Islam. Materi PAI ini memiliki karakteristik tertentu. Sumber lain menyatakan,

Pendidikan agama memiliki karakteristik tersendiri yang berbeda dengan mata pelajaran lainnya. Pendidikan Agama Islam (PAI), memiliki karakteristik sebagai berikut: (1) PAI berusaha untuk menjaga akidah peserta didik agar tetap kokoh dalam situasi dan kondisi apapun; (2) PAI berusaha menjaga dan memelihara ajaran dan nilai-nilai yang tertuang dan terkandung dalam al- Qur'an dan Hadits serta otentisitas keduanya sebagai sumber utama ajaran Islam; (3) PAI menonjolkan kesatuan iman, ilmu dan amal dalam kehidupan keseharian; (4) PAI berusaha membentuk dan mengembangkan kesalehan individu dan sekaligus kesalehan sosial; (5) PAI menjadi landasan moral dan etika dalam pengembangan ipteks dan budaya serta aspek - aspek kehidupan lainnya; (6) substansi PAI mengandung identitas-identitas yang bersifat rasional dan suprarasional; (7) PAI berusaha menggali, mengembangkan dan mengambil

15. Syafruddin Nurdin, Guru Profesional \& Implementasi Kurikulum, (Jakarta: Ciputat Press, 2002), h. 16-17 
ibrah dari sejarah dan kebudayaan (peradaban) Islam, dan (8) dalam beberapa hal, PAI mengandung pemahaman dan penafsiran yang beragam, sehingga memerlukan sikap terbuka dan toleran atau semangat ukhuwah islamiyah. ${ }^{16}$

Karakteristik tersebut menuntut profesionalisme guru PAI makin kompleks lagi. Karena itu, profesionalisme guru PAI paling tidak harus memenuhi sepuluh macam kreteria, yaitu: (1) kemampuan menguasai materi PAI; (2) kemampuan menguasai rumpun ilmu alat dalam memahami materi PAI; (3) kemampuan menjelaskan materi PAI dengan menggunakan perspektif berbagai bidang keilmuan lainnya yang terkait; (4) kemampuan mendidikkan dan mengajarkan PAI kepada peserta didik dengan baik; (5) kemampuan menguasai metodologi pemikiran dan pemahaman PAI dengan baik; (6) kemampuan me-manage pembelajaran PAI dengan maksimal; (7) kemampuan mengamalkan kesalehan individual dan kesalehan sosial dalam perilaku keseharian; memiliki pengalaman mendalam dalam mendidik dan mengajar peserta didik; (9) memiliki komitmen memberikan layanan prima kepada peserta didik; dan (10 ) memiliki motivasi kerja atas dasar ibadah (pengabdian).

Efektifitas proses pembelajaran di dalam maupun di luar kelas sangat ditentukan oleh kompetensi para guru, disamping faktor lain seperti anak didik, lingkungan dan fasilitas. Selain mentransfer pengetahuan, guru juga bertugas sebagai motivator, fasilitator dan dinamisator dalam proses pembelajaran. Kompetensi profesional guru harus senantiasa ditingkatkan guna menambah pengetahuan dan ketrampilan, terutama untuk menjadi guru yang profesional. Dalam usaha peningkatan profesionalisme guru tersebut tentu terdapat faktor pendukung dan juga penghambat tercapainya peningkatan profesionalisme guru.

Apabila profesionalisme guru dikaitkan dengan program sertifikasi, maka program sertifikasi inilah yang menjadi faktor pendukung utama bagi peningkatan profesionalisme guru PAI. Tunjangan sertifikasi

16. Muhaimin, Nuansa Baru Pendidikan Islam Mengurai Benang Kusut Dunia Pendidikan, 
(kenaikan gaji) merupakan usaha untuk meningkatkan profesionalimse guru. Hal ini dapat dilihat dari tujuan sertifikasi guru sendiri, sebagaimana dikutip di bawah ini:

Ada dua target pelaksanaan sertifikasi guru:

1. Meningkatnya kompetensi kepribadian, kompetensi profesional, kompetensi pedagogis, dan kompetensi sosial guru

2. Meningkatnya profesionalisme, kinerja dan kesejahteraan guru. ${ }^{17}$

Berdasarkan hal tersebut di atas, pemerintah memberikan tunjangan kepada guru-guru yang dapat menjalankan tugas profesionalismenya dengan baik melalui program sertifikasi guru. Program sertifikasi guru merupakan upaya pemerintah untuk mengidentifikasikan guru-guru berkualitas. Guru berkualitas yang terbukti dari hasil sertifikasi dijadikan dasar untuk memberikan tunjangan profesi. Guru yang memperoleh tunjangan profesi dikategorikan sebagai guru profesional.

Sertifikasi merupakan salah satu upaya dalam meningkatkan profesionalisme guru, sebagai sebuah proses ilmiah yang memerlukan pertanggung-jawaban akademis dan moral. Dalam sertifikasi terdapat suatu uji kelayakan yang harus dilaksanakan seorang guru terhadap kriteria-kriteria yang telah ditetapkan.

Dalam rangka peningkatan profesionalisme guru, hal yang diujikan dalam adalah bekaitan degan kompetensi guru. Sebagaimana yang termaktub dalam Undang-Undang Guru dan Dosen Pasal 10 dan Peraturan Pemerintah tentang Standar Nasional Pendidikan Pasal 28, kompetensi guru meliputi kompetensi pedagogik, kepribadian, profesional, dan sosial. $^{18}$

Pada sertifikasi guru dalam jabatan, usaha peningkatan terhadap keempat kompetensi tersebut dilakukan dalam bentuk penilaian portofolio yang diarahkan pada komponen mengikuti pendidikan dan pelatihan,

(Jakarta: PT. Raja Grafindo Persada, 2006), h. 102

17.Jamal Ma'ruf Asmani, 7 Tips Cerdas \& Efektif Lulus Sertifikasi Guru, (Yogyakarta: Diva Press, 2009), h. 29

18. Masnur Muslich, Sertifikasi Guru Menuju Profesionalisme Pendidik,.... h. 12 
penilaian dari atasan atau pengawas, keikutsertaan dalam forum ilmiah, pengalaman organisasi di bidang kependidikan dan sosial, dan penghargaan yang relevan dengan bidangnya. ${ }^{19}$

Berdasarkan pada penjelasan di atas dapat dimaknai bahwasanya sertifikasi adalah sebuah program yang diadakan demi tewujudnya profesionalisme guru dalam menjalankan tugas-tugasnya sebagai pendidik. Dapat diartikan bahwa, dengan sertifikasi akan berdampak positif bagi guru seperti meningkatnyapengetahuan dan wawasan tentang tugas dan fungsi guru sebagai tenaga profesional, meningkatnya penguasaan terhadap kurikulum dan pembelajaran sertamengubah mindset guru sebagai sebuah pekerjaan profesional.

\section{1) Metode penelitian}

Penelitian ini mengunakan pendekatan kualitatif yang berbentuk studi kasus, dengan metode penelitiannya yakni, wawancara (interview) bebas terpimpin, observasi, dokumentasi. Peneliti menggunakan teknik interview bebas terpimpin yang ditujukan Kepala Sekolah dan Guru PAI bersertifikasi yang terdiri dari dua sekolah yakni SMP Negeri 1 dan SMP Negeri 2 . Interview peneliti tujukan kepada pada Bapak Purnomo, S.Pd selaku Kepala SMP Negeri 1 Punggur, Bapak Tri Purnomo, S.Pd selaku Kepala SMP Negeri 2 Punggur, serta kepada tujuh orang guru PAI bersertifikasi di SMP Negeri 1 dan SMP Negeri 2 Punggur. Wawancara ini peneliti lakukan secara berkala sejak tanggal 02 September 2018 sampai dengan 13 Desember 2018.

Teknik wawancara ini peneliti lakukan secara langsung guna memperoleh informasi tentang peningkatan profesionalisme guru PAI melalui program sertifikasi di SMP se-Kecamatan Punggur.Tehnik observasi yang dipakai Peneliti adalah observasi non partisipan yaitu mengadakan pengamatan terhadap aktivitas obyek tertentu dimana peneliti

19. Masnur Muslich, Sertifikasi Guru Menuju Profesionalisme Pendidik,.... h. 13-18 
tidak aktif mengikuti aktivitas obyek tersebut. Adapun hal-hal yang diobservasi meliputi lokasi penelitian, sarana dan fasilitas, keadaan lingkungan, konsep data peningkatan profesionalisme guru melalui program sertfikasi. Observasi ini Peneliti lakukan guna mengetahui kelengkapan sarana pendukung dalam peningkatan profesionalisme guru PAI bersertifikasi di SMP se Kecamatan Punggur. Metode dokumentasi dijadikan sebagai pelengkap untuk memperoleh keterangan tentang data-data yang diperlukan penulis dengan jalan mengumpulkan bukti-bukti tertulis atau tercetak, gambar, dan sebagainya. Adapun dokumen yang diperlukan dalam penelitian ini adalah nama, data lengkap dari objek penelitian dan buku-buku yang berkaitan dengan penelitian.Selain itu data yang akan dijadikan dokumentasi yaitu denah lokasi, susunan kepengurusan, sejarah, jumlah anggota, serta foto kegiatan penelitian. Gunanya sebagai data pelengkap dalam penelitian di SMP se-Kecamatan Punggur.

\section{2) Hasil penelitian}

\section{a. Program Sertifikasi}

Ada beberapa bentuk program dalam peningkatan profesionalisme guru PAI dalam menunjang satu persatu kompetensinya pedagogik, personal, profesional maupun sosialnya. Program tersebut antara lain dapat dilakukan melalui pelatihan, seminar, workshop, kegiatan forum ilmiah , supervisi pendidikan, aktif dalam organisasi kependidikan dan sosial dan lain sebagainya. Tujuannya adalah untuk meningkatkan pengetahuan, sikap kepribadian maupun sosial dan sikap profesionalnya.

Berdasarkan beberapa penuturan dari para responden, maka analisis peningkatan profesionalisme guru PAI melalui program sertifikasi dalam kompetensi pedagogik terbilang memuaskan. Hal ini terlihat dari usaha guru-guru PAI di SMP se-Kecamatan Punggur yang betul-betul mengasah keterampilan mereka dalam mengajar. Selanjutnya peningkatan dalam kompetensi profesional terbilang cukup memuaskan, hal ini dapat diketahui dari hasil wawancara yang menyatakan bahwa guru-guru PAI di SMP 
se-Kecamatan Punggur telah memenuhi beberapa indikator guru profesional, yakni menguasai bahan, menguasai program belajar, mengelola kelas, menggunakan media dan sumber belajar, menguasai landasan kependidikan, mengelola interaksi belajar mengajar, menilai prestasi siswa untuk kepentingan pengajaran, dan memahami prinsip-prinsip pengajaran. Begitu pula dengan peningkatan profesionalisme pada kompetensi personal dan sosial guru PAI di SMP se-Kecamatan Punggur yang sudah cukup memuaskan, akan tetapi masih ada bebarapa komponen profesionalisme pada tiap kompetensi yang belum dapat dipenuhi oleh guru-guru PAI bersertifikasi.

\section{b. Peningkatan Profesionalisme Guru PAI melalui Program Sertifikasi}

Berdasarkan temuan penelitian seperti dipaparkan sebelumnya, dapat dikemukakan bahwa peningkatan profesionalisme guru PAI melalui program sertifikasi sudah memuaskan meskipun belum begitu signifikan. Masih terdapat beberapa komponen profesionalisme yang belum terpenuhi. Program sertifikasi yang tujuannya untuk meningkatkan profesionalisme dan kesejahteraan guru masih begitu dipertanyakan. Kesejahteraan boleh jadi meningkat, akan tetapi belum diiringi dengan meningkatnya profesionalisme sebagaimana yang diharapkan. Hal ini terbukti dari temuan penelitian yang mengungkap bahwa guru-guru PAI bersertifikasi di SMP se-Kecamatan Punggur belum memenuhi kriteria-kriteria guru profesional sebagaimana diharapkan.

Kriteria-kriteria di atas meliputi kompetensi pedagogik, personal, profesional, sosial, dan juga kegiatan-kegiatan penunjang peningkatan profesionalisme guru seperti seminar, pelatihan, workshop, supervisi, dan lain-lain. Guru-guru bersertifikasi seharusnya memenuhi beberapa kriteria di atas, namun masih ada beberapa komponen dalam indikator guru profesional belum dijalankan. Selain itu, kurangnya pengawasan dari supervisor Pendidikan Agama Islam yang hanya mengawasi kinerja guru PAI secara tidak langsung. Berdasarkan bunyi Surat Keputusan Menteri Pendayagunaan Aparatur Negara No 118 tahun 1996 Bab I pasal I ayat (1) 
yang menyatakan bahwa pengawas sekolah/madrasah adalah Pegawai Negeri Sipil (PNS) yang diberi tugas, tanggung jawab dan wewenang untuk melaksanakan pengawasan di sekolah/madrasah dengan melakukan penilaian dan pembinaan dari segi teknis pendidikan dan administrasi pada satuan pendidikan pra-sekolah, sekolah dasar dan menengah. Para pengawas memiliki peran sebagai:

1. Peneliti

Artinya, pengawas pendidikan mempunyai tugas untuk menjadi seorang peneliti, yakni berperan meneliti tentang kinerja guru-guru yang berada dalam binaannya. Meneliti disini bukan hanya meneliti kelemahan-kelemahan yang ada pada diri guru akan tetapi meneliti segala aspek yang ada pada diri guru guna mengetahui seberapa profesional seorang guru dalam menjalankan tugasnya.

2. Konsultan/Penasehat

Seorang pengawas pendidikan berperan sebagai konsultan atau penasehat bagi guru-guru yang diawasinya. Hal ini untuk mengetahui apa yang menjadi kesulitan guru dalam menjalankan tugas profesionalnya di sekolah yang selanjutnya diberikan solusi pemecahannya.

Tugas pokok penasehat meliputi advice mengenai sekolah sebagai sistem, memberi nasehat kepada guru tentang pembelajaran yang efektif, memberi nasehat kepada kepala sekolah dalam mengelola pendidikan dan staf sekolah dalam meningkatkan kinerja sekolah.

3. Fasilitator

Artinya, seorang pengawas pendidikan seharusnya berperan sebagai fasilitator yang mampu memfasilitasi warga sekolah terutama guru agar dapat melakukan pengembangan profesinya secara berkelanjutan.

4. Motivator

Peran sebagai motivator, seorang supervisor pendidikan harus mampu mempengaruhi, menggerakkan, memberdayakan, dan mendorong 
sehingga seluruh komponen pendidikan dapat berkembang secara profesional.

Berdasarkan hasil wawancara dengan pengawas pendidikan Agama Islam di lingkungan Kecamatan Punggur, didapatkan hasil wawancara sebagai berikut:

"Pengawasan yang dilakukan di sekolah umum di lingkungan Kecamatan Punggur menggunakan teknik pengawasan tidak langsung dengan cara menindak lanjuti hasil laporan guru PAI setiap bulannya. Hal ini dilakukan karena mengingat jarak tempuh daerah pengawasan Kemenag Lampung Tengah yang sangat luas dan kurangnya anggaran kepengawasan. Pengawas disini berperan sebagai peneliti, evaluator, dan konsultan, akan tetapi sesekali kami mendatangi sekolah-sekolah untuk pengawasan secara langsung”.

Seharusnya, supervisor pendidikan memberikan motivasi dan pembinaan kepada guru-guru PAI bersertifikasi yang berada dibawah binaannya agar kinerja dan profesionalisme guru-guru PAI yang telah tersertifikasi dapat terjaga dan meningkat dibandingkan sebelum mendapat tunjangan profesi.

Terlepas dari manusia tiada yang sempurna, setidaknya ada usaha guru-guru PAI bersertifikasi untuk meningkatkan kompetensinya, selain itu pengawasan harus dilakukan secara ketat dan berkala oleh supervisor Pendidikan Agama Islam. Melihat bahwa kesejahteraannya sudah dipenuhi, seharusnya ada feed back yang seimbang guna memajukan pendidikan Islam di Indonesia.

Berdasarkan hasil observasi peneliti terhadap data keguruan di SMP se Kecamatan Punggur diketahui bahwa telah ada usaha peningkatan profesionalisme guru PAI yang terlihat dari adanya kegiatan-kegiatan rutin yang diwacanakan oleh sekolah seperti mengadakan kegiatan seminar, pelatihan, forum ilmiah, workshop, semiloka dan lain sebagainya, namun keikutsertaan guru-guru PAI khususnya yang sudah bersertifikasi masih tergolong minim. Bila dikaji menggunakan teknik triangulasi, maka hasil observasi ini tentunya relevan dengan hasil wawancara dan dokumentasi 
terhadap guru-guru PAI bersertifikasi dan Kepala Sekolah di SMP Se Kecamatan Punggur.

\section{Kesimpulan}

Berdasarkan pemantauan di lapangan, meneliti, menganalisa dan mengolah data yang telah dilakukan, maka dapat diabil kesimpulan sebagai berikut: Peningkatan profesionalisme guru PAI melalui program sertifikasi sudah memuaskan, akan tetapi belum sepenuhnya berjalan sebagaimana yang diharapkan. Program sertifikasi yang tujuannya untuk meningkatkan kesejahteraan guru belum terlaksana sebagaimana mestinya. Kesejahteraan boleh jadi meningkat, akan tetapi tidak diiringi dengan meningkatnya profesionalisme sebagaimana yang diharapkan. Hal ini terbukti dari temuan penelitian yang mengungkap bahwa guru-guru PAI bersertifikasi di SMP se-Kecamatan Punggur belum memenuhi kriteria-kriteria guru profesional sebagaimana diharapkan. Faktor pendukung dalam peningkatan profesionalisme guru adalah, kenaikan gaji tunjangan sertifikasi, kebijaksanaan pimpinan sekolah dalam mendorong guru PAI untuk mengikuti berbagai kegiatan akademik yang dapat meningkatkan profesionalismenya seperti pelatihan, penataran atau pemberian kesempatan pada guru untuk sekolah lagi, dan usaha keras yang dilakukan oleh pribadi guru PAI sendiri untuk meningkatkan profesionalismenya dengan cara belajar terus-menerus. Faktor penghambat dalam peningkatan profesionalisme guru yaitu, desakan kebutuhan masyarakat dan sekolah akan guru, sulitnya standar mutu guru dikendalikan dan dijaga, PGRI belum banyak aktif melakukan kegiatan-kegiatan yang lan berkaitan dengan peningkatan profesionalisme guru, seperti mengadakan seminar, semiloka, forum ilmiah, pelatihan, dan perubahan yang terjadi di masyarakat melahirkan tuntutan-tuntutan baru terhadap peran yang seharusnya dimainkan oleh guru. 


\section{DAFTAR PUSTAKA}

Abbas, ABBAS. "Pengembangan Profesionalisme Guru.” Adaara: Jurnal Manajemen Pendidikan Islam, 2018. https://doi.org/10.35673/ajmpi.v7i1.310.

Andrian, Yusuf, and Rusman Rusman. 'Implementasi pembelajaran abad 21 dalam kurikulum 2013'. Jurnal Penelitian Ilmu Pendidikan 12, no. 1 (25 April 2019): 14-23. https://doi.org/10.21831/jpipfip.v12i1.20116.

Macbeath, John. "Future of Teaching Profession." Education International Research Institute, 2012.

Muhali, Muhali. 'Pembelajaran Inovatif Abad Ke-21'. Jurnal Penelitian dan Pengkajian Ilmu Pendidikan: e-Saintika 3, no. 2 (31 December 2019): 25-50. https://doi.org/10.36312/e-saintika.v3i2.126.

Nuraeni, Zuli, and Heri Retnawati. "The Post-Certification Performance of Mathematics Teachers.” The Online Journal of New Horizons in Education, 2016.

Pautina, Amalia Rizki. 'Aplikasi Teori Gestalt dalam Mengatasi Kesulitan Belajar Pada Anak’ 6 (2018): 15.

Prayogi, Rayindra Dwi, and Rio Estetika. "Kecakapan Abad 21: Kompetensi Digital Pendidik Masa Depan.” Jurnal Manajemen Pendidikan 14, no. 2 (2019).

Rohmansyah, Nur Azis. 'Implikasi Teori Gestalt Dalam Pendidikan Jasmani Sekolah Dasar’. Malih Peddas (Majalah Ilmiah Pendidikan Dasar) 7, no. 2 (18 April 2018): 195. https://doi.org/10.26877/malihpeddas.v7i2.1858.

Rosichin Mansur, Pengembangan Kurikulum Pendidikan Agama Islam Multikultural (Suatu Prinsip-prinsip Pengembangan), Jurnal Ilmiah Vicratina, Volume 10, No. 2, Nopember 2016.

Saleh, Yopa Taufik. "Sertifikasi Untuk Meningkatkan Profesionalisme Guru." NATURALISTIC : Jurnal Kajian Penelitian Pendidikan Dan Pembelajaran, 2017. https://doi.org/10.35568/naturalistic.v1i1.42.

Sanaky, Hujair A.H. "Sertifikasi Dan Profesionalisme Guru Di Era Reformasi Pendidikan.” Jurnal Pendidikan Islam, Jurusan Tarbiyah, 2005.

Sutarmanto. “Kompetensi Dan Profesionalisme Guru.” Jurnal Visi Ilmu Pendiidkan, 2015. 
Syamsul Bahri, Pengembangan Kurikulum Dasar dan Tujuannya, Jurnal Ilmiah ISLAM FUTURA, Volume XI, No. 1, Agustus 2011.

Ulwiyah, Nur. 'Landasan Psikologi Dan Aktualisasinya Dalam Pendidikan Islam'. Religia: Jurnal Studi Islam Vol. 6, no. No. 1 (April 2015): 24.

Wiwin Fachrudin Yusuf, Implementasi Kurikulum 2013 (K-13) Pada Mata Pelajaran Pendidikan Agama Islam Sekolah Dasar (SD), Al-Murabbi: Jurnal Pendidikan Agama Islam, Volume 3 Nomor 2, Juni 2018.

Yunita Hariyani, Prinsip-prinsip Pengembangan Kurikulum dalam Upaya Meningkatkan Kualitas Pembelajaran, Jurnal Pendidikan Agama Islam, Vol. 2, No. 2, Juli-Desember 2018.

Yusuf, Achmad. 'Pengembangan Kurikulum PAI Berbasis Multikultural (Perspektif Psikologi Pembelajaran)'. AL MURABBI 4, no. 2 (25 May 2019): 251-74. https://doi.org/10.35891/amb.v4i2.1453.

Yusuf, Achmad. 'Pengembangan Kurikulum PAI Berbasis Multikultural (Perspektif Psikologi Pembelajaran)'. AL MURABBI 4, no. 2 (25 May 2019): 251-74. https://doi.org/10.35891/amb.v4i2.1453. 
